\title{
Ontogeny of the articulated yiliangellinine trilobite Zhangshania typica from the lower Cambrian (Series 2, Stage 3) of southern China
}

\author{
Jin-bo Hou, ${ }^{1,2}$ Nigel C. Hughes, ${ }^{2}$ Jie Yang, ${ }^{1}$ Tian Lan, ${ }^{3}$ Xi-guang Zhang, ${ }^{1}$ and Chrysalyn Dominguez ${ }^{2}$ \\ ${ }^{1}$ Key Laboratory for Paleobiology, Yunnan University, Kunming 650091, China〈houjinboo@gmail.com〉; 〈yangjie@ynu.edu.cn〉; \\ 〈xgzhang@ynu.edu.cn〉 \\ ${ }^{2}$ Department of Earth Sciences, University of California, Riverside CA 92521, USA 〈nigel.hughes@ucr.edu $\rangle$; $\langle\mathrm{cdomi} 009 @ \mathrm{ucr} . e d u\rangle$ \\ ${ }^{3}$ College of Resources and Environmental Engineering, Guizhou University, Guiyang 550003, China〈Lantianing@sina.com〉
}

\begin{abstract}
New discoveries of the early Cambrian yiliangellinine trilobite Zhangshania typica Li and Zhang in Kunming preserve almost all instars from early postembryonic (protaspid) to mature (holaspid) phases in articulated state, in addition to mature specimens with antennae bearing paired spines on the basal articles. The ontogenetic series shows protarthrous development with some, but likely not all, early holaspid instars expressing additional pygidial segments, gradual rearward migration of the location of the longest pleural spines on the trunk segments, and striking positive allometry of the genal spines. It also reveals Parazhangshania sichuanensis Li and Zhang, 1990 to be the holaspid stage 3 of Z. typica, and therefore its junior synonym. This new find in the Hongjingshao Formation provides species-based regional correlation across the South China block and Z. typica may provide an important biostratigraphic marker for the base of the traditional Tsanglangpuan Stage.
\end{abstract}

\section{Introduction}

Trilobite ontogenies reveal important information about the development, evolution, and systematics of this large, wellrepresented fossil clade. Ontogenetic information increases character data available for a given taxon by revealing a wider array of states than those seen in mature forms alone, and can also help in constraining the polarity of evolutionary change. Particularly complete ontogenetic series, based on articulated specimens, also offer insight into ontogenetic changes among sets of characters located throughout the exoskeleton that reveal coordinated morphological change during development. An example is the sequential construction of the mature trunk from segmental building blocks during the anamorphic phase of development (Minelli et al., 2003). Where ontogenies are unusually rich both in terms of the span of instars represented and in the number of individuals available for each instar, it is possible to frame and test specific hypotheses about how aspects of development were controlled (e.g., Fusco et al., 2004, 2014). In such cases, direct insights into the processes that governed ancient arthropod growth can be revealed. Such studies can permit characterization of developmental processes that operated at nodes deep within the euarthropod clade, and illustrate the essential relevance of paleontological data to evolutionary developmental biology. Likewise, understanding how ontogeny evolved across Trilobita will illuminate the history of developmental control within an extinct clade.

At present, the number of articulated trilobite taxa with ontogenetic series sufficiently well known to permit such work is restricted to a single species - the Silurian aulacopleurid Aulacopleura koninckii. While tempting to consider this as a "model animal" for trilobite development, its phylogenetic position is quite derived within the clade (Hughes et al., 1999). Furthermore, A. koninckii shows unique variation in the number of thoracic segments in the epimorphic phase (see Hughes et al., 2006). Although this feature makes the species particularly valuable as a study system, it also illustrates its anomalous nature. The approach taken with A. koninckii must now be expanded to a variety of other trilobites, including those showing different morphotypes and developmental modes. In this regard, the early Cambrian is a particularly fruitful interval on which to focus for several reasons. Firstly, its trilobites are phylogenetically basal and might thus yield insights into the original developmental condition of the clade from which forms such as A. koninckii may have departed. Secondly, several relatively complete ontogenies of articulated species are already known from this time, mostly from parts of China (e.g., Dai et al., 2014; Hou et al., 2015). Among Chinese members of the superfamily Redlichioidea Poulsen, 1927, relatively complete ontogenies have been described for Redlichia chinensis (see Kobayashi and Kato, 1951) and Eoredlichia intermediata (see Dai and Zhang, 2013). The ontogeny of Z. typica complements these by providing the first description of the articulated ontogeny for any member of the redlichiid family Gigantopygidae Harrington in Harrington et al., 1959. This expands the range of examples, but within a relatively small group, allowing insight into the evolutionary lability of developmental traits.

Even at the current state of knowledge, some developmental issues are coming into focus: although $E$. intermediata, Z. typica, Tsunyidiscus yanjiazhaiensis, and Sinodiscus changyangensis were all protarthrous species, early Cambrian 
trilobites varied in whether or not termination of trunk segment expression preceded termination of developing segment articulation (Hughes et al., 2006, table 1; Zhang and Clarkson, 2012). Such variation was also common among derived species. On the other hand, meraspid growth of early Cambrian polymerid trilobites had prolonged pygidial equilibrium phases (Simpson et al., 2005) and few, if any, such species had any trunk segment longer than their first segment in that body region. That condition is different from that of many derived species, including A. koninckii, in which the longest segment was located posterior to the leading trunk segment. This difference is important both because it offers the possibility of surprisingly detailed insight into the nature of growth control in these ancient animals (e.g., Fusco et al., 2014, 2016), and because elevated growth rates of posterior segments were likely critical to the production of several derived trilobites body plans. Diligent collecting of ontogenetic series of articulated specimens of early Cambrian species thus offers rich promise for further insights into the controls of early arthropod evolution and development.

Herein, we describe ontogenetic development of the nearly complete, articulated early Cambrian yiliangelline trilobite
Zhangshania typica $\mathrm{Li}$ and Zhang, 1990 in Li et al., 1990 as a first step in establishing it as a candidate for more extensive, quantitative investigation when sample size permits.

\section{Geological setting and biostratigraphic correlation}

Zhangshania typica characterizes a regional biozone in Sichuan Province of southern China (Li et al., 1990; Xiang et al., 1999). Our new report of its occurrence in Kunming permits refined correlation between Sichuan and eastern Yunnan province (Fig. 1). $\mathrm{Li}$ et al. (1990) divided the Yuxiansi Formation of Leshan in Sichuan into two members, the lower being the Zhangshan Member, where the species described herein was first reported (Fig. 1.1), and an upper unit called the Youfanggou Member. They recognized a Yiliangella-Zhangshania biozone in the upper part of the Zhangshan Member in Leshan that they correlated with the Yunnanaspis-Yiliangella biozone of the Yunnan area (Zhou and Yuan, 1980), also known as the Yiliangella biozone, which is the earliest trilobite zone of the Tsanglangpuan Stage (Luo et al., 2008) based on Yiliangella's widespread distribution in the Hongjingshao Formation. These correlations
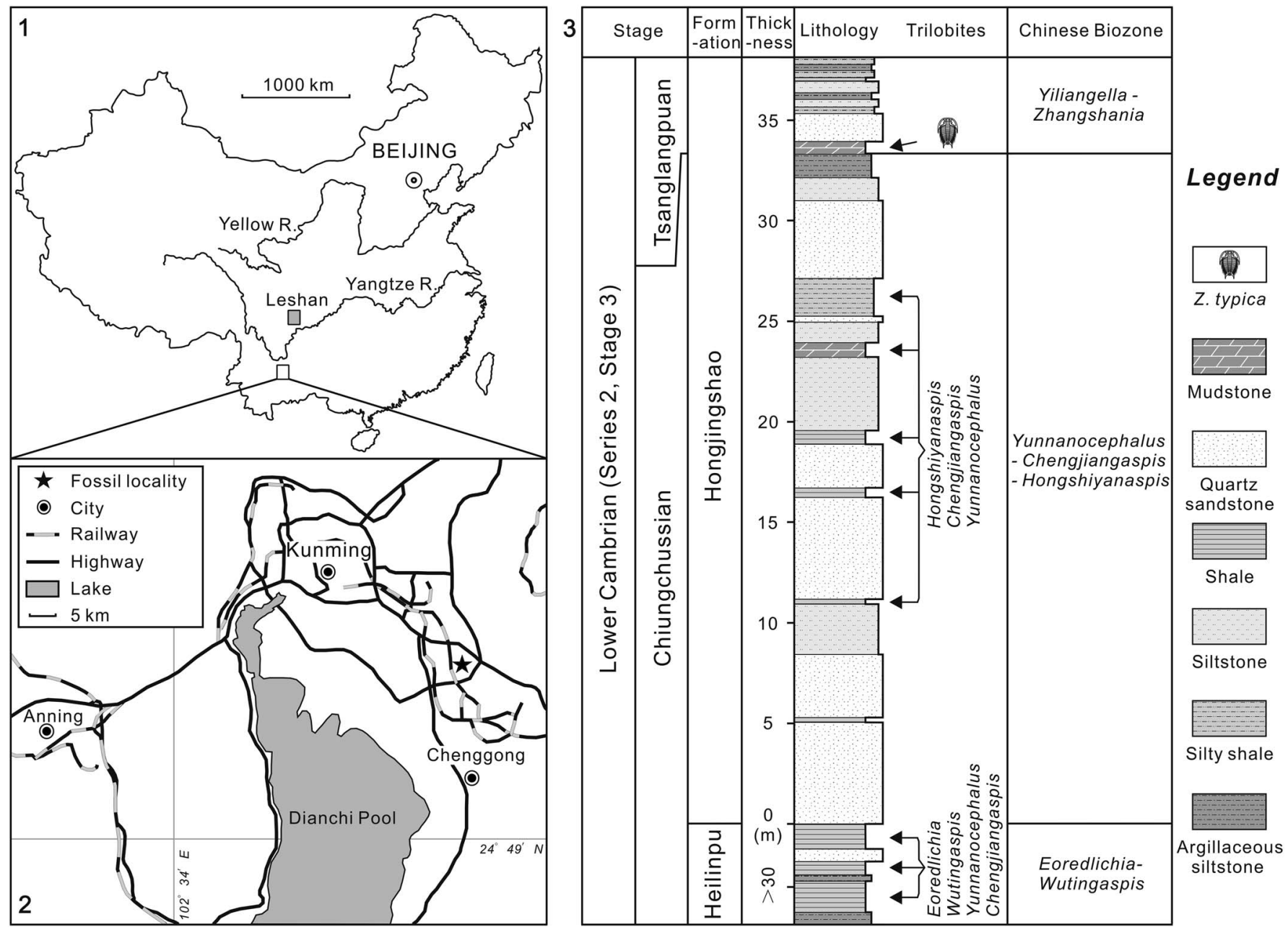

Figure 1. Locality map and stratigraphic section: (1), sketch map showing the positions of two localities reported with Zhangshania typica; (2), location map of the studied fossil site (marked with a star) in the early Cambrian Hongjingshao Formation, Kunming, Yunnan Province; (3), lithological section through the trilobite-bearing strata of the exposed Hongjingshao Formation in Kunming. The upper mudstone represents the level from which the species described in this paper has been collected. 


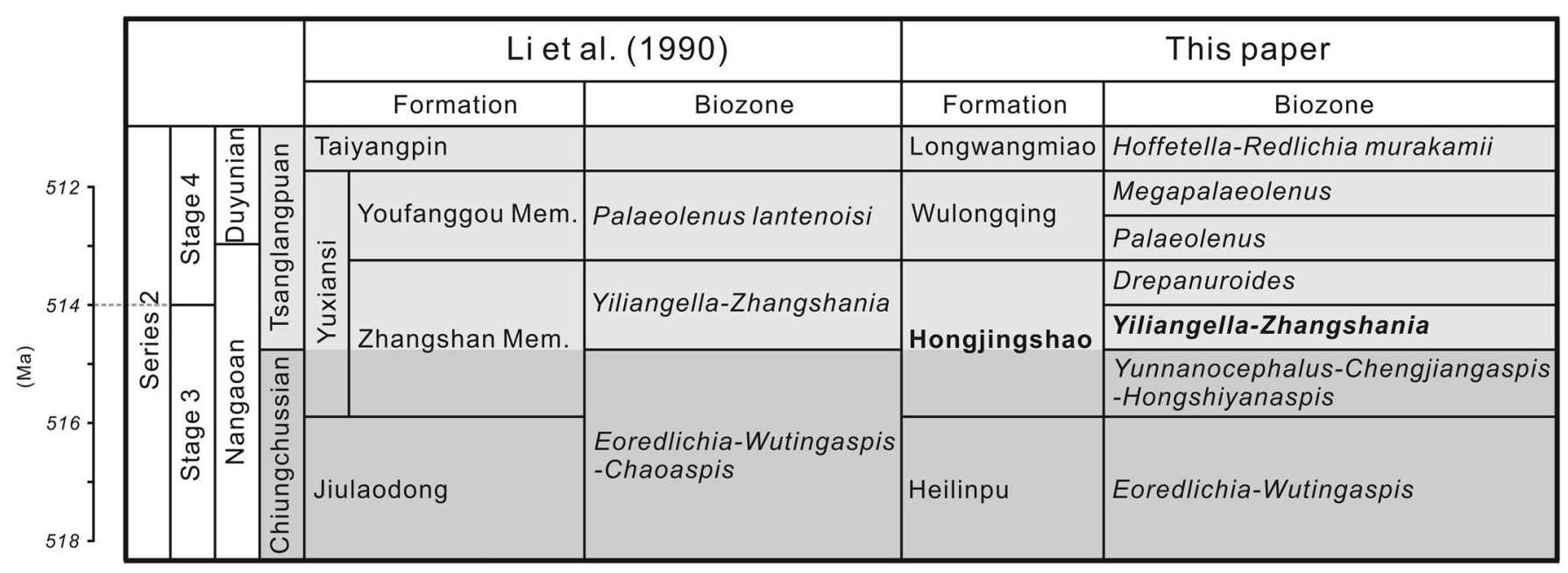

Figure 2. Stratigraphic correlation between Sichuan province and Yunnan province (modified from Li et al., 1990; Luo et al., 2008; Peng, 2009; Peng et al., 2012; Yang et al., 2013, 2014). Mem. = Member.

suggest that the Hongjingshao and Wulongqing formations of eastern Yunnan might correlate with the Zhangshan and Youfanggou members, respectively (Figs. 1.2,2). Because our material of Z. typica comes from a level at about $34 \mathrm{~m}$ above the base of the lower part of the Hongjingshao Formation of eastern Yunnan, which can be up to $130 \mathrm{~m}$ thick (Luo et al., 2008), it provides strong evidence in support of the correlation of the basal parts of both the Hongjingshao Formation and the Zhanshan Member, and is an important regional stratigraphic tie across southern China. Here, we apply the term YiliangellaZhangshania biozone in the Yunnan area (Fig. 2), but also note that Zhangshania may occur stratigraphically below Yiliangella in this area. The first occurrence of Z. typica might thus serve as a marker of the base of the Tsanglangpuan Stage of the traditional Chinese early Cambrian stages (correlative with the uppermost Nangaoan Stage of Peng et al., 2012) (Figs. 1.3, 2).

\section{Materials and methods}

The almost complete ontogenetic series described herein was collected from the Xiaoshiba Lagerstätte, which has yielded extraordinarily preserved fossils (Yang et al., 2013, 2014, 2015, 2016a, 2016b). The site is located within Kunming, Yunnan Province, southern China (Fig. 1.1, 1.2) where the lower $37 \mathrm{~m}$ of the Hongjingshao Formation are exposed (Yang et al., 2014). It consists of a thick-bedded sandstone unit, occasionally interspersed with thin-bedded siltstones and shales deposited in an offshore, shelfal marine environment. The fossiliferous layer is located within a mudstone, about $0.9 \mathrm{~m}$ thick, where complete specimens with soft-tissues and hypostomes in original position are preserved along with material that shows various degrees of disarticulation. The best-preserved specimens represent either carcasses or intact exuviae that were likely buried rapidly (Speyer and Brett, 1986), but other specimens show a variety of degrees of disarticulation. One specimen with antennae shows detachment of both free cheeks (Fig. 5.2). This presumably is a carcass, either of an animal preserved in the act of ecdysis, or one from which the free cheeks detached during decay of an intact carcass. Such an appendage-bearing specimen cautions against interpreting axial shields with detached free checks as exuviae rather than carcasses (e.g., Brandt, 2002). Specimens are found at multiple horizons within the 0.9-m unit, and it appears that individual horizons vary in the portions of ontogeny that are represented, with some horizons notable for clusters of early meraspids commonly associated with fragments of larger skeletal debris, while others are dominated by dispersed holaspids. The assemblage somewhat resembles accumulations of $A$. koninckii in the Aulacopleura shales of the Silurian of the Czech Republic, which also yield a complete record of trilobite ontogeny (Hughes et al., 2014). However, the overall density of Z. typica specimens is far lower and the clustering pattern of smaller individuals around skeletal debris is different from the surfaces hosting densely packed A. koninckii (Hughes et al., 2014).

Repositories and institutional abbreviations.-The specimens described and illustrated in this paper are housed in the collections of the Key Laboratory for Paleobiology, Yunnan University (YKLP).

\section{Systematic paleontology}

Morphological terms and abbreviations largely follow those of Whittington and Kelly (1997) and Hughes et al. (2006). Where characters are not described in a given stage, they remain as described in the previous stage. Abbreviations used: exs. = exsagittal; $\mathrm{H} 1-\mathrm{H} 4$, holaspid stages 1 to 4 , respectively; M0-M13 = meraspid degrees 0 to 13 , respectively; S1-S3 = glabellar furrows 1 to 3 , respectively; sag. = sagittal; $\mathrm{T}=$ trunk; tr. $=$ transverse.

Order Redlichiida Richter, 1932

Suborder Redlichiina Harrington in Harrington et al., 1959 Superfamily Redlichioidea Poulsen, 1927

Remarks.-Several of the principal variations used to distinguish groups within this diverse superfamily include the number of mature trunk segments and the allocation of these segments to the mature thorax and pygidium. Some members have small holaspid pygidia containing as few as two segments and 
relatively large numbers of holaspid thoracic segments (up to 17 or more), whereas others have substantial holaspid pygidia comprised of multiple segments (7 or more) and fewer mature thoracic segments ( 9 or fewer). Until a phylogenetic analysis of the group is completed, it will remain unclear as to whether the families currently recognized constitute monophyletic groups, whether changes in mature trunk segment allocation evolved multiple times within the group, and what the polarities of any such trends were. Nevertheless, the group does appear to offer a promising study system for exploring aspects of trunk evolution among early trilobites (see McNamara, 1986).

Family Gigantopygidae Harrington in Harrington et al., 1959

Remarks.-This group is among those redlichiid trilobites with relatively large pygidia and an intermediate number of mature thoracic segments. Gigantopygidae are considered by Jell and Adrain (2003) to include the type species, Gigantopygus papillatus Hupé 1953 from Morocco, along with several other species described from the same region; Bornemannaspis, a form known only from cranidia collected in Sardina (Rasetti, 1972); and various other genera that are here all considered to belong to the subfamily Yiliangellinae. Gigantopygus papillatus differs from members of the Yiliangellinae in its prominent fixigenal bacculae, and Bornemannaspis, which is too poorly know to be assigned to the family with confidence and was placed in Redlichiidae by Chang et al. (in Kaesler, 1997).

Subfamily Yiliangellinae Zhang and Lin, in Zhang et al., 1980

Remarks.—Chang et al. in Kaesler, 1997 considered the subfamily Yiliangellinae to include only three genera: Yiliangella, Yiliangellina, and Zhangshania, but two other giganotopygid genera mentioned by Jell and Adrain (2003, p. 471) fit within Chang et al.'s (in Kaesler, 1997) definition. These are Parayiliangella Luo in Luo et al., 1994 and Pseudoyiliangella Yin in Yin and Li, 1978. The latter is based on a single cranidium and is not considered further below. Systematically important morphological differences within Yiliangellinae are discussed in the Remarks section for the genus.

Zhangshania $\mathrm{Li}$ and Zhang in $\mathrm{Li}$ et al., 1990 was first reported from the Yuxiansi Formation of Leshan in Sichuan (Fig. 1.1). It was considered similar to Yiliangella Chang, 1966 and Yiliangellina Chang, 1966, and thus placed in the subfamily Yiliangellinae Zhang and Lin in Zhang et al., 1980. Those authors also erected another genus, Parazhanshania Li and Zhang in Li et al., 1990, whose sole species we synonymize with Z. typica below.

Genus Zhangshania Li and Zhang in Li et al., 1990

Type species.-Zhangshania typica $\mathrm{Li}$ and $\mathrm{Zhang}$ in $\mathrm{Li}$ et al. (1990, pl. 2, figs. 1-6), collected from the lower Cambrian Yuxiansi Formation, Yiliangella-Zhangshania Biozone, in Leshan, Sichuan Province, China.

Remarks.-Li et al. (1990) distinguished Zhangshania from Parazhangshania on the basis of the latter having a small mature dorsal exoskeleton, a narrow brim, non-bifurcated eye ridges, large palpebral lobes, a relatively narrow glabella with a rounded anterior end, a very short preglabellar field, and a wide and short axial lobe on the pygidium. However, these supposed differences between the two genera are characteristics of the holaspid phase 3 of Z. typica (see below). Accordingly, Parazhangshania is a junior subjective synonym of Zhangshania.

Yiliangella is very similar to Zhangshania, but differs by having a smaller palpebral lobe and a long eye ridge that is not bifurcated. In addition, there are sixteen holaspid thoracic segments and a pygidium with two pairs of pygidial spines in Yiliangella, whereas Zhangshania has fourteen holaspid thoracic segments and one pair of pygidial spines.

A conical glabella with weakly incised glabellar furrows and a long preglabellar field differentiates Yiliangellina from Zhangshania. The holaspid thorax of the former is composed of fifteen segments, and it also has two pairs of spines on the pygidium. Parayiliangella differs from Zhangshania in the former's notably smaller palpebral lobes and the presence of fifteen holaspid thoracic segments.

Several taxa outside the Yiliangellinae also closely resemble Zhangshania, including several yinitid taxa. If phylogenetic analysis reveals a trend within Redlichioidea toward a more segment-rich pygidium, it is possible that giganotopygids are a paraphyletic sister group of Yinitidae. Yinites Lu, 1945 differs from Zhangshania in having a larger glabella, a non-bifurcated eye ridge, and a long anterior border. Yinites has thirteen holaspid thoracic segments, each with short pleural spines, and a pygidium with a single pair of long spines that are preceded by two pairs of small spines.

The yinitid Drepanopyge Lu, 1961 (emended by Chang, 1966) is distinguished from Zhangshania in having ten holaspid thoracic segments, each with short pleural spines, and by a pygidium with five pairs of short and wide spines. Malungia $\mathrm{Lu}$, 1961 (emended by Chang, 1966) is differentiated from Zhangshania by its long preglabellar field that is of similar length to the anterior border that curves forward strongly. Malungia also has a small pygidium with a pair of long, wide, flat, and sharp spines.

Zhangshania typica $\mathrm{Li}$ and Zhang in Li et al., 1990

Figures 3.1-3.9, 4.1-4.6, 5.1-5.6; Supplementary Data 1.1-1.6, $2.1-2.12,3.1-3.9$

1990 Zhangshania typica $\mathrm{Li}$ and Zhang in Li et al., p. 44, pl. 2, figs. 1-3, 5, 6 .

1990 Parazhangshania sichuanensis $\mathrm{Li}$ and Zhang in Li et al., p. 47 , pl. 3, figs. 1-4, 6, 7, 10, 11 .

Holotype.-A complete specimen, Ly-312 (Chengdu Institute of Geology and Mineral Resources) (Li et al., 1990, pl. 2, fig. 1); counterpart of the holotype Ly-313 (Li et al., 1990, pl. 2, fig. 2). Paratypes: a nearly complete hypostome, Ly-314 (Li et al., 1990, pl. 2, fig. 3); a nearly complete cranidium, Ly-315 (Li et al., 1990, pl. 2, fig. 4); a nearly complete pygidium, Ly-316 (Li et al., 1990, pl. 2, fig. 5); a complete pygidium, Ly-317 ( $\mathrm{Li}$ et al., 1990, pl. 2, fig. 6). All of these specimens are here assigned to holaspid stage 4. 

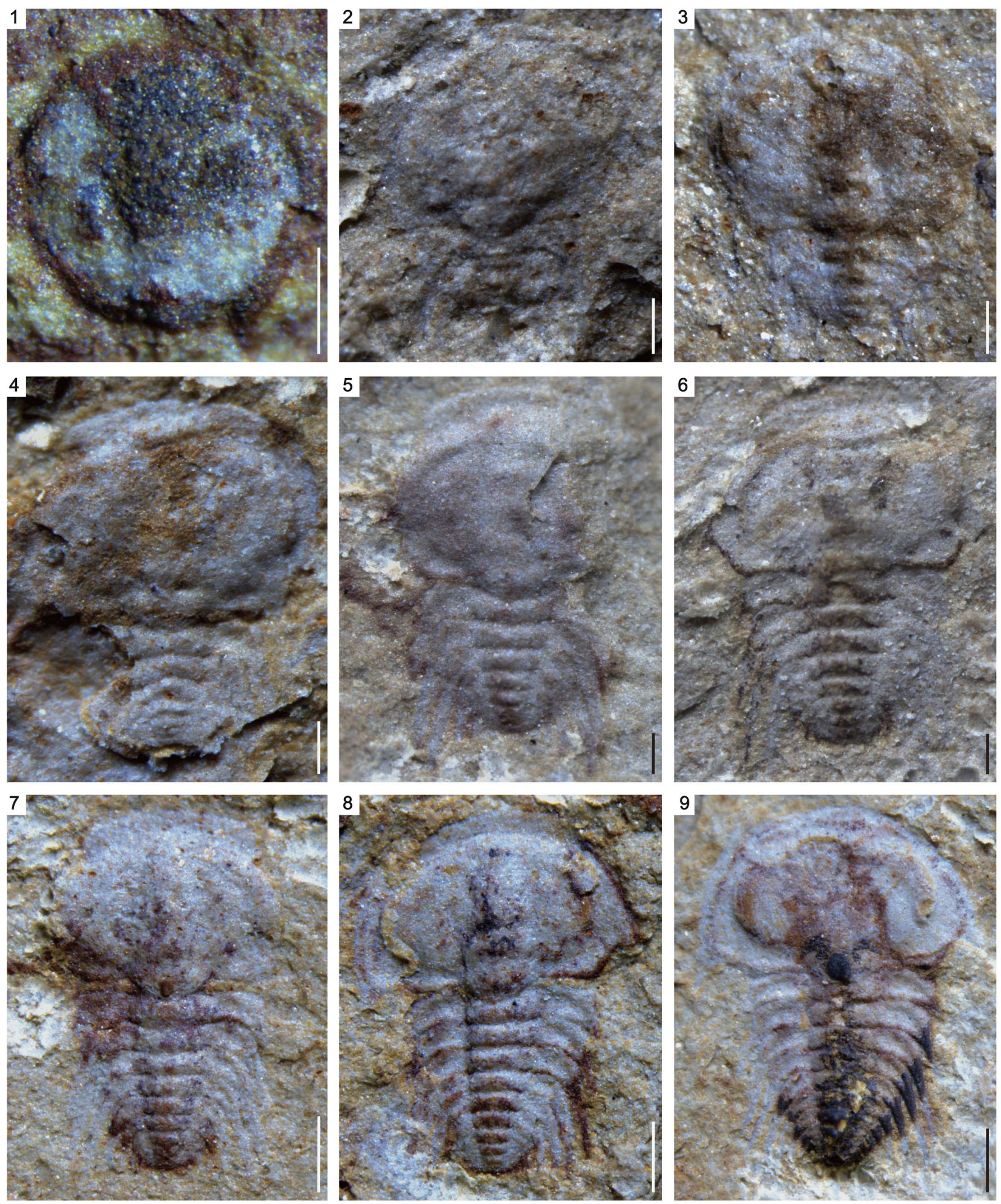

Figure 3. Supposed protaspid and meraspides of Zhangshania typica from the Hongjingshao Formation, in Kunming, Yunnan Province, southern China: (1), supposed protaspid of this species, YKLP 12249; (2), Meraspid degree 2, YKLP 12250; (3), Meraspid degree 3, YKLP 12251; (4) Meraspid degree 4, YKLP 12252; (5), Meraspid degree 5, YKLP 12253; (6), Meraspid degree 6, YKLP 12254; (7), Meraspid degree 7, YKLP 12255; (8), Meraspid degree 8, YKLP 12256; (9), Meraspid degree 9, YKLP 12257. Scale bars are (1-6) $200 \mu \mathrm{m} ;(7-9) 500 \mu \mathrm{m}$. 

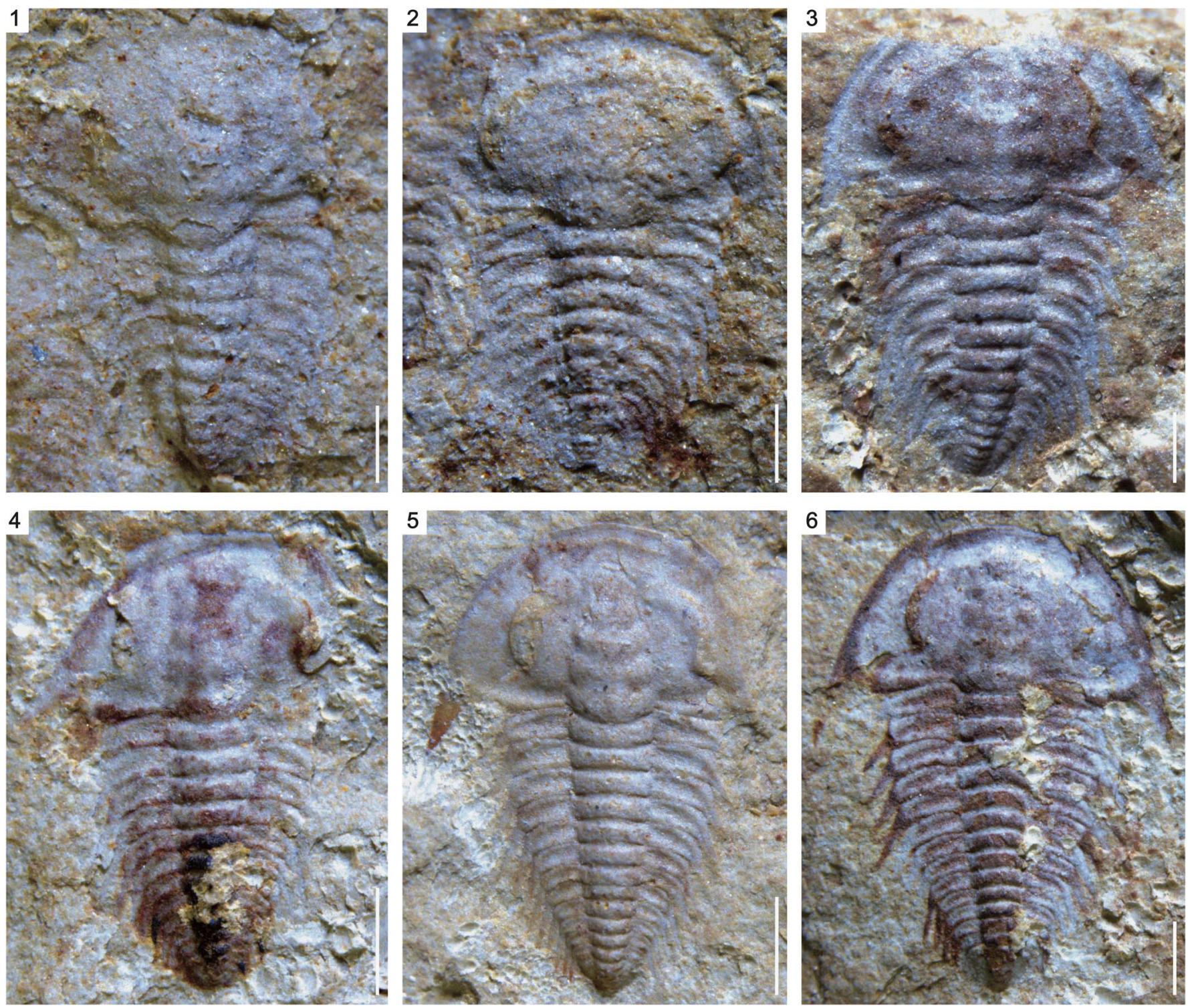

Figure 4. Meraspides and early holaspides of Zhangshania typica from the Hongingshao Formation, in Kunming, Yunnan Province, southern China: (1), Meraspid degree 10, YKLP 12258; (2), Meraspid degree 11, YKLP 12259; (3), Meraspid degree 12, YKLP 12260; (4), Meraspid degree 13, YKLP 12261; (5), Holaspid stage 1, YKLP 12262; (6), Holaspid stage 2, YKLP 12263. Scale bars are (1-3) $500 \mu \mathrm{m} ;(\mathbf{4 - 6 )} 1.00 \mathrm{~mm}$.

Protaspis.-Represented by one specimen (Figs. 3.1, 6.1; Supplementary Data 1.1-1.2; Table 1). Exoskeleton about $0.55 \mathrm{~mm}$ long. Cephalon circular, convex, $0.48 \mathrm{~mm}$ long and $0.54 \mathrm{~mm}$ wide, characterized by a furrow differentiating it from trunk. Axial furrow wide (tr.), deep, terminating at conjunction between eye ridge and frontal glabellar lobe. Fixigena slightly convex, 1.5 times wider than glabella (measured at midpoint of second glabellar lobe). Lateral and posterior borders narrow, convex. Occipital ring cylindrical, convex, with medial node. Occipital furrow deep. Trunk short (sag.), curved downward with at least one convex axial ring.

Meraspis.-Sixty-one specimens were assigned to the meraspid phase and range from 0.96 to $4.55 \mathrm{~mm}$ in sagittal length (Figs. 3.2-3.9, 4.1-4.4, 6.2-6.13; Supplementary Data 1.3-1.6, 2.1-2.12, 3.1-3.5; Table 1).
Degree 2 (M2).--Represented by four articulated specimens (Figs. 3.2, 6.2; Supplementary Data 1.3, 1.4; Table 1). Length varies between 0.96 and $1.22 \mathrm{~mm}$. Cephalon sub-circular in outline. Cranidium quadrate, convex. Glabella cylindrical, convex, extending forward to anterior border furrow, with three weakly impressed transglabellar furrows: S1 and S2 shallow adaxially, paralleling each other, extending slightly backward adaxially; S3 shallow, extending transversely. Frontal glabellar lobe large, quadrate, extending to anterior border furrow. Occipital ring large, convex, increasing length (sag.) adaxially, with medial node. Occipital furrow transverse, deep and long (sag.). Fixigena slightly convex, slightly narrower (tr.) than glabella. Anterior border long (sag.) and of even length (exs.), convex, curved forward slightly. Anterior border furrow deep. Axial furrow deep, extending forward up to S3. Palpebral lobe apparently small, two fifths of cephalic length 

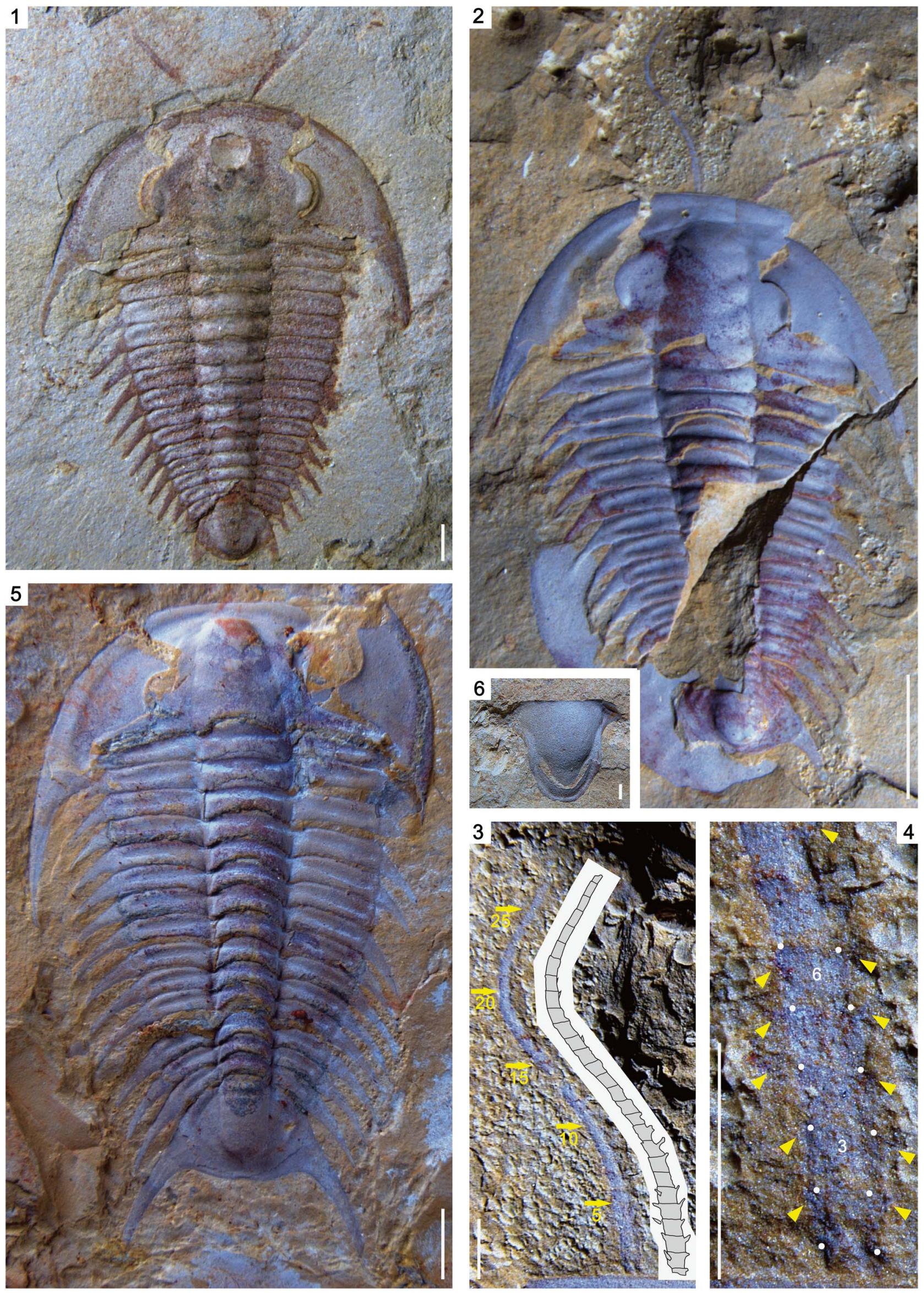
(sag.), located opposite glabellar lobes 2 and 3. Anterior branches of facial suture divergent anterolaterally. Posterior branches of facial suture divergent posterolaterally. Lateral border narrow (tr.), slightly convex. Lateral border furrow and posterior border furrow shallow. Posterior border slightly convex, becoming gradually shorter (exs.) towards occipital ring. Librigena narrow (tr.). Trunk axis convex, each thoracic segment with small axial node. Pleural lobe extending transversely, slightly narrower (tr.) than axis. Thoracic pleural spine equivalent length on both segments, extending backward well beyond pygidium. Pleural furrow deep, extending posterolaterally. Pygidium small, sub-rectangular in outline. Axis convex, tapering backward, divided into three distinct segments, anterior two with small axial node. Pleural spines appear on each of anterior two segments, first longer than second, both extending well beyond pygidium. Pleural furrows and interpleural furrows weakly impressed.

Degree 3 (M3).--Represented by four articulated specimens (Figs. 3.3, 6.3; Supplementary Data 1.5, 1.6; Table 1). Length varies between 1.14 and $1.26 \mathrm{~mm}$. Eye ridge long (exs.), convex, length (exs.) same as palpebral lobe width (tr.), fused with frontal glabellar lobe and extending posteriorly to fuse with palpebral lobe. Thoracic pleural spines extend beyond posterior margin of pygidium, anterior two of equivalent length and longer than third spine. Pygidial border narrow.

Degree 4 (M4).--Represented by nine articulated specimens (Figs. 3.4, 6.4; Supplementary Data 2.1-2.3; Table 1). Length varies between 1.28 and $1.70 \mathrm{~mm}$. Genal spine at posterior of small librigena, not extending posterolaterally beyond occipital furrow, advanced. Lateral border narrow (tr.), slightly convex, width (tr.) same as anterior border length (sag.). Lateral border furrow shallow, wide (tr.). Thoracic pleural spines long, anterior two of equivalent length, then decreasing in length from third to fourth.

Degree 5 (M5).--Represented by seven articulated specimens (Figs. 3.5, 6.5; Supplementary Data 2.4; Table 1). Length varies between 1.52 and $1.90 \mathrm{~mm}$. Cranidium trapezoid. Thoracic pleural spines long, all except first pleural spine extending beyond posterior margin of pygidium. Anterior three thoracic pleural spines of nearly equivalent length, then decreasing in length from fourth to fifth spine.

Degree 6 (M6).--Represented by seven articulated specimens (Figs. 3.6, 6.6; Supplementary Data 2.5, 2.6; Table 1). Length varies between 1.64 and $2.12 \mathrm{~mm}$. Thoracic pleural spines long, all extending beyond posterior margin of pygidium, except for first and second pleural spines. Anterior four thoracic pleural spines of nearly equivalent length, then decreasing in length from fifth to sixth. Pygidium with three pairs of pleural spines present, decreasing in size rearwards.

Degree 7 (M7).--Represented by three complete specimens (Figs. 3.7, 6.7; Supplementary Data 2.7, 2.8; Table 1).
Length varies between 2.26 and $2.37 \mathrm{~mm}$. Axial furrow extending slightly beyond S3. First thoracic pleural spines shorter than the following three, which are of equivalent length, after which length gradually decreases posteriorly.

Degree 8 (M8).--Represented by eight articulated specimens (Figs. 3.8, 6.8; Supplementary Data 2.9, 2.10; Table 1). Length varies between 2.14 and $2.57 \mathrm{~mm}$. Cephalon subcircular in outline. Librigena half fixigenal width (tr.). Fixigena convex slightly, slightly wider than half glabellar width. Relative length of thoracic pleural spines increases rearward in first five thoracic segments and thereafter decreases.

Degree 9 (M9).--Represented by six complete specimens (Figs. 3.9, 6.9; Supplementary Data 2.11, 2.12; Table 1). Length varies between 2.35 and $2.85 \mathrm{~mm}$. Relative length of long thoracic pleural spines increases rearward in first five thoracic segments and thereafter decreases.

Degree 10 (M10).- Represented by four articulated specimens (Figs. 4.1, 6.10; Supplementary Data 3.1; Table 1). Length varies between 2.84 and $3.05 \mathrm{~mm}$. Relative length of pleural spines increases rearward in first five thoracic segments, decreasing thereafter, with the posterior tips of the rearward trunk spines all extending posteriorly to roughly the same extent, forming an ontogenetically transient fringe of spines of approximately equal posterior extent.

Degree 11 (M11).--Represented by three articulated specimens (Figs. 4.2, 6.11; Supplementary Data 3.2; Table 1). Length varies between 2.84 and $3.87 \mathrm{~mm}$. Genal spine extends posterolaterally almost to posterior margin of cephalon. Pleural spine lengths approximately equal throughout much of thorax, but longest in mid-thorax. Posterior of trunk extends farther rearward than tips of longest thoracic pleural spines.

Degree 12 (M12).--Represented by two articulated specimens (Figs. 4.3, 6.12; Supplementary Data 3.3; Table 1). Fixigena slightly convex, half glabellar width. Librigena of medium-size, same width (tr.) as fixigena. Genal spine extends posterolaterally up to T1. Pleural spines lengths approximately equal throughout much of thorax, longest in mid-thorax. Pygidial pleural spine seemingly absent on third pygidial segment.

Degree 13 (M13).--Represented by four complete specimens (Figs. 4.4, 6.13; Supplementary Data 3.4, 3.5; Table 1). Length varies between 3.72 and $4.55 \mathrm{~mm}$. Axial furrow deep, extending forward to merge with anterior border furrow. Librigena large, slightly wider than fixigena. Genal spine protruding strongly posterolaterally up to $\mathrm{T} 2$. Pygidial axis convex, divided into three indistinct segments, with pleural spine only showing on 14th trunk segment. Two pairs of pleural lobe furrows and one pair of interpleural lobe furrows present, extending posterolaterally. Posterior border narrow. Posterior margin rounded.

Figure 5. Late holaspides of Zhangshania typica from the Hongjingshao Formation, in Kunming, Yunnan Province, southern China: (1), Holaspid stage 3, YKLP 12264; (2), Holaspid stage 3, YKLP 12265; (3), enlargement and accompanied drawing of left antenna of the specimen in Figure 5.2: the yellow arrows indicate the upper boundaries of corresponding segments that are marked by yellow numbers; (4), enlargement of the proximal part of the antenna in figure 5.3; the paired yellow arrowheads indicate two spines on both sides of the associated article, except where a single arrowhead denotes one spine on the right side distally; white points represent the boundaries between articles; (5), Holaspid stage 4, YKLP 12266; (6), a single hypostome, YKLP 12267. Scale bars are $(\mathbf{1}, \mathbf{3}, \mathbf{4}, \mathbf{6}) 1.0 \mathrm{~mm} ;(\mathbf{2}, \mathbf{5}) 5.0 \mathrm{~mm}$. 
1

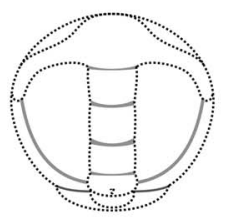

I

6

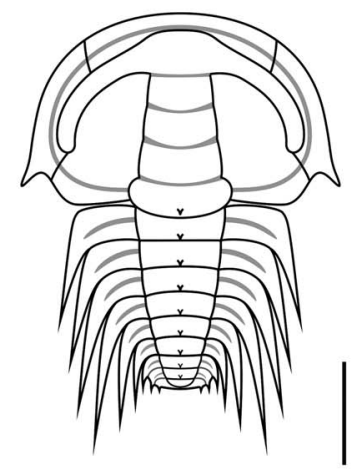

10

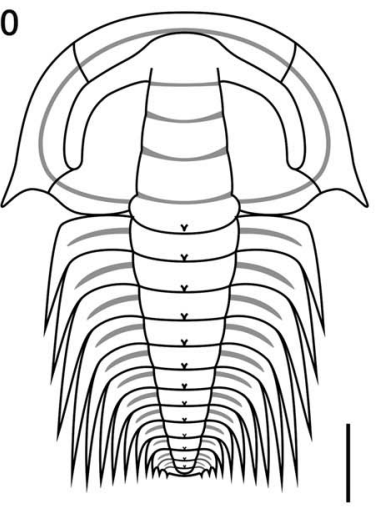

14

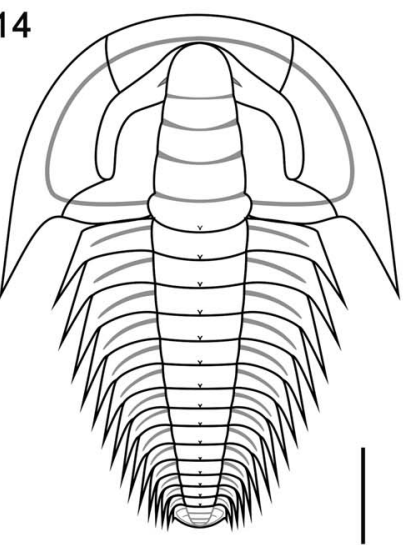

2

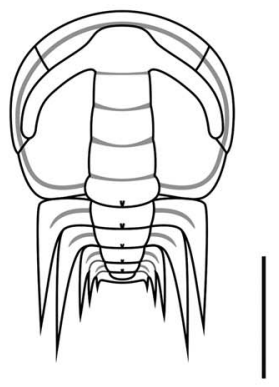

7

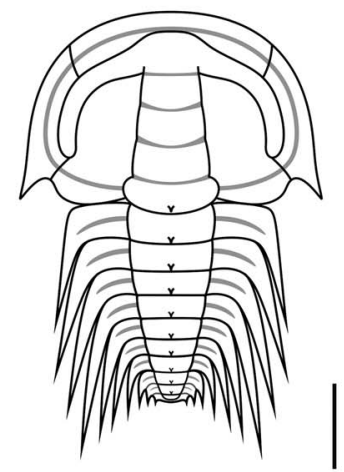

11

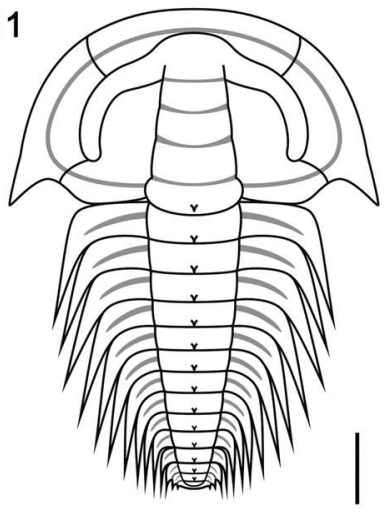

15

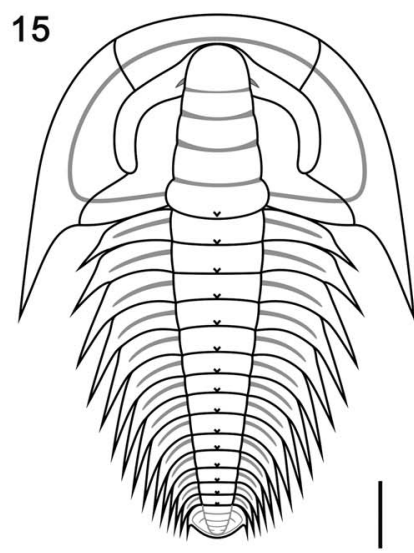

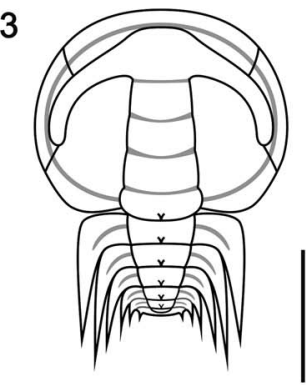

8

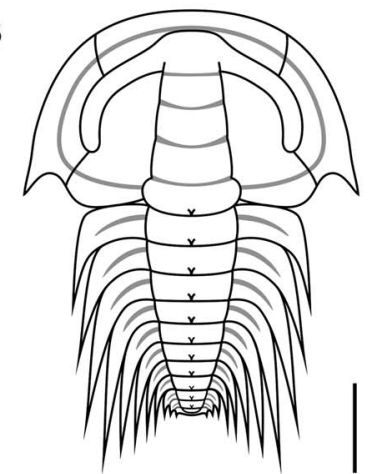

12

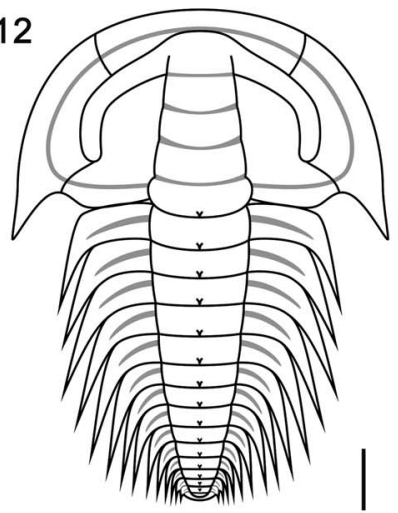

16

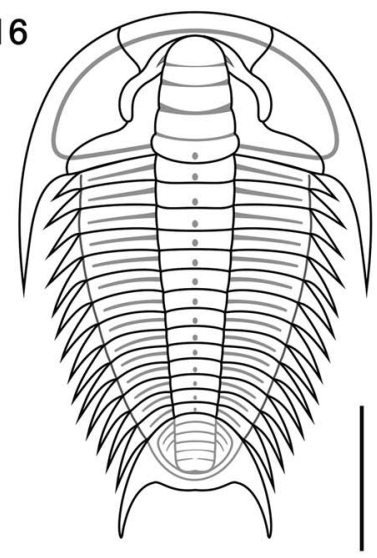

4

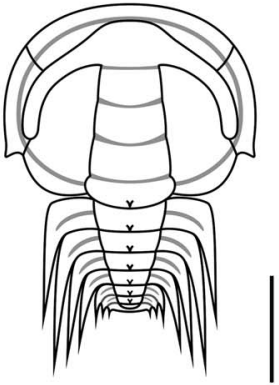

5

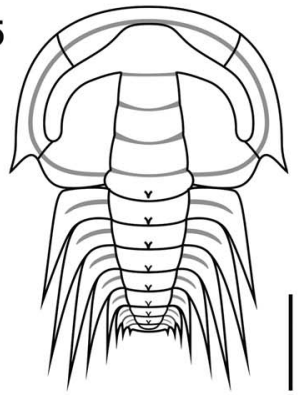

9

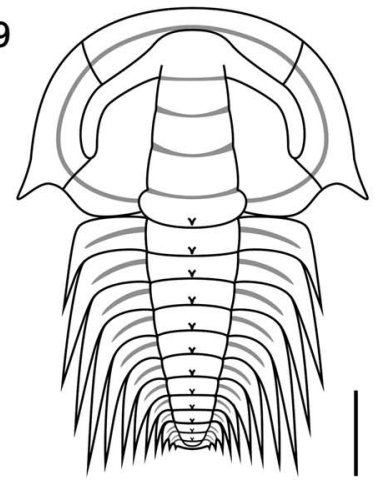

13
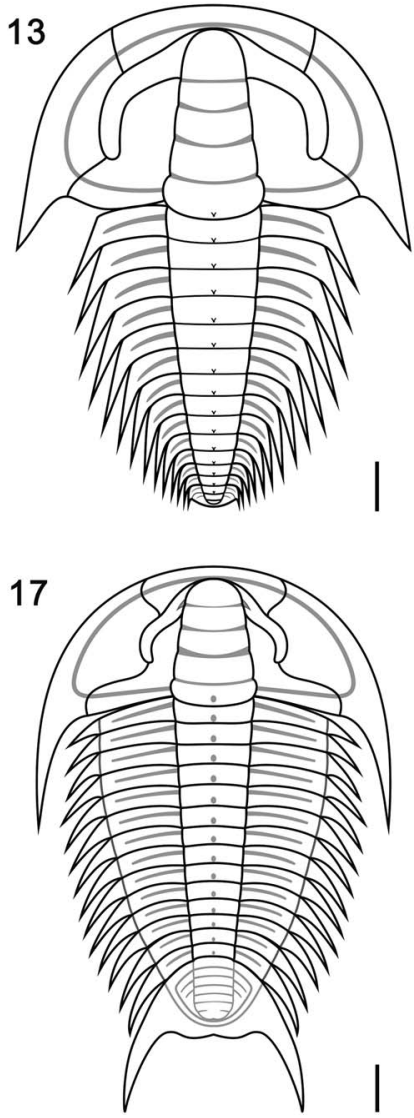

Figure 6. Reconstructions of the dorsal exoskeleton of ontogenetic series of Zhangshania typica: (1), supposed protaspis of this species based on specimen YKLP 12249; (2), meraspid degree 2; (3), meraspid degree 3; (4), meraspid degree 4; (5), meraspid degree 5; (6), meraspid degree 6; (7), meraspid degree 7; (8), meraspid degree 8; (9), meraspid degree 9; (10), meraspid degree 10; $(\mathbf{1 1})$, meraspid degree 11; (12), meraspid degree 12; (13), meraspid degree 13; (14), holaspid stage 1; (15), holaspid stage 2; (16), holaspid stage 3; (17), holaspid stage 4. Scale bars are (1-13) 500 $\mu$; $(\mathbf{1 4 - 1 5 )} 1.0$ mm; (16-17) $5.0 \mathrm{~mm}$. 
Table 1. Morphometric data summarizing the size changes during the ontogenetic series of Zhangshania typica described in this paper. The units are in millimeters $(\mathrm{mm})$.

\begin{tabular}{|c|c|c|c|c|c|c|}
\hline & \multirow{2}{*}{$\begin{array}{l}\text { Exoskeleton } \\
\text { Length }\end{array}$} & \multicolumn{2}{|c|}{ Cranidium } & \multicolumn{2}{|c|}{ Pygidium } & \multirow{2}{*}{$\begin{array}{l}\text { Pygidial spine } \\
\text { Length }\end{array}$} \\
\hline & & Length & Width & Length & Width & \\
\hline$\overline{\mathrm{M} 2}$ & $0.96-1.22$ & $0.63-0.72$ & $0.50-0.61$ & $0.10-0.17$ & $0.21-0.37$ & \\
\hline M3 & $1.14-1.26$ & $0.71-0.81$ & $0.59-0.68$ & $0.09-0.15$ & $0.21-0.28$ & \\
\hline M4 & $1.28-1.70$ & $0.70-0.93$ & $0.69-0.80$ & $0.11-0.16$ & $0.26-0.35$ & \\
\hline M5 & $1.52-1.90$ & $0.86-1.07$ & $0.76-0.87$ & $0.12-0.17$ & $0.26-0.38$ & \\
\hline M6 & $1.64-2.12$ & $0.83-1.05$ & $0.84-0.90$ & $0.07-0.22$ & $0.18-0.45$ & \\
\hline M7 & $2.26-2.37$ & $1.08-1.17$ & $0.89-1.00$ & $0.15-0.17$ & $0.32-0.40$ & \\
\hline M8 & $2.14-2.57$ & $1.01-1.22$ & $0.95-1.10$ & $0.09-0.22$ & $0.24-0.42$ & \\
\hline M9 & $2.35-2.85$ & $1.06-1.28$ & $1.01-1.12$ & $0.11-0.22$ & $0.27-0.39$ & \\
\hline M10 & $2.84-3.05$ & $1.22-1.31$ & $1.13-1.25$ & $0.12-0.18$ & $0.33-0.40$ & \\
\hline M11 & $2.84-3.87$ & $1.19-1.55$ & $1.21-1.34$ & $0.10-0.32$ & $0.32-0.69$ & \\
\hline M12 & - & 1.55 & 1.28 & 0.14 & 0.28 & \\
\hline M13 & $3.72-4.55$ & $1.50-1.93$ & $1.30-1.63$ & $0.12-0.23$ & $0.23-0.46$ & \\
\hline $\mathrm{H} 1$ & $4.53-6.55$ & $1.73-2.26$ & $1.52-1.90$ & $0.23-0.43$ & $0.50-0.67$ & \\
\hline $\mathrm{H} 2$ & $5.26-11.28$ & $1.84-3.67$ & $1.47-3.11$ & $0.34-1.34$ & $0.53-1.67$ & $0.09-0.68$ \\
\hline $\mathrm{H} 3$ & $8.96-27.06$ & $2.87-7.50$ & $2.49-7.28$ & $0.95-3.73$ & $1.10-5.50$ & $0.28-6.24$ \\
\hline $\mathrm{H} 4$ & $32.51-85.00$ & $8.69-22.00$ & $8.19-23.00$ & $5.49-10.82$ & $6.26-17.52$ & $6.79-13.03$ \\
\hline
\end{tabular}

Holaspid period.-60 specimens ranging in size from 4.53 to $85.0 \mathrm{~mm}$ long (Figs. 4.5, 4.6, 5.1-5.6, 6.14-6.17; Supplementary Data 3.6-3.9; Table 1), all of which have fourteen thoracic segments. They are divided into a series of stages based on the number of segments expressed in the pygidium. Stage 1 (H1).-Represented by three specimens (Figs. 4.5, 6.14; Supplementary Data 3.6, 3.7; Table 1). Length varies from 4.53 to $6.55 \mathrm{~mm}$. Glabella conical, convex, extending forward to anterior border furrow, rounded in front. Eye ridge long (exs.), convex, bifurcated, fused with frontal glabellar lobe and front of glabellar lobe 3, extending posterolaterally and gradually becoming short (exs.). Occipital ring slightly curved rearward adaxially, with small medial node weakly expressed. Fixigena gently convex, slightly narrower than half glabellar width. Librigena wide (tr.). Genal spine extending up to T2, base located opposite posterior corner of cranidium. Lateral border slightly convex, same width (tr.) as anterior border length (sag.). Thoracic axis convex, each segment with small central node. Pygidial axis convex, divided into four segments. Pleural lobe triangular, extending posteriorly into single pair of short pygidial spines. Two pairs of pleural furrows weakly impressed. Stage 2 (H2).-Represented by 18 articulated specimens (Figs. 4.6, 6.15; Supplementary Data 3.8, 3.9; Table 1). Length varies between 5.26 and $11.28 \mathrm{~mm}$. Preglabellar field short. Fixigena narrow and flat, less than half glabellar width. Anterior branches of facial suture markedly anterolaterally divergent. Posterior branches of facial suture extend strongly outward and then curve backward. Posterior area of fixigena short (sag.) and wide (tr.). Librigena wide, one and half times width of fixigena. Genal spine slender, extending posteriorly up to T3. Pleural spines increasing in length from the first to fifth pleural spines, after which spine lengths decrease gradually backwards. Pygidium of moderate size. Axis convex, divided into five segments. Pleural lobe triangular with pleurae sloping downward, with two pleural furrows weakly impressed extending posterolaterally. Pygidial spine extends backward beyond pygidial margin. Border narrow.

Stage 3 (H3).-Represented by 32 articulated specimens (Figs. 5.1-5.4, 6.16; Table 1). Length varies between 8.96 and $27.06 \mathrm{~mm}$. Antennae slightly longer than cephalic length, tapering distally, consist of at least 28 articles.
Articles range from width (tr.) slightly longer than length (exs.) at base of antennae to width almost half of article length terminally. Proximal six articles, each ornamented with pair of sharp spines on anterior corners. More distal articles with single sharp, adaxially directed spine. Cephalon semi-circular in outline. Cranidium sub-trapzoidal, convex. Glabella conical, convex, extending forward almost to anterior border furrow, rounded in front. Three transglabellar furrows weakly impressed, shallowest axially: S1 and S2 extend backward slightly adaxially; S3 shallow, transverse. Anterior lobe of hypostomal median body elliptical, distinctly convex. Preglabellar field short (sag.) but distinct. Eye ridge slightly convex, bifurcated, fused anteriorly with frontal glabellar lobe and front of glabellar lobe 3, tapering posterolaterally to fuse with palpebral lobe. Palpebral lobe small, two fifths of cephalic length, convex, located opposite of glabellar lobes 2 and 3. Axial furrow wide (tr.) and deep, extending forward into anterior border furrow. Anterior border of constant length (sag.), curved forward slightly. Anterior border furrow shallow. Anterior branches of facial suture diverging lateral strongly and then sweeping adaxially forward, posterior branches of facial suture diverging laterally, then sweeping backward to posterior margin. Fixigena narrow, flat, one third of glabellar width. Librigena flat, wider (tr.) than twice width of fixigena. Genal spine long, extending backward to T4 or T5. Lateral border narrow (tr.), slightly convex, widening posteriorly. Lateral border furrow shallow. Occipital furrow shallow, curved posteriorly slightly. Occipital ring curves posteriorly slightly adaxially, with small axial medial node. Thoracic pleural lobe subrectangular, slightly wider (tr.) than axial width (tr.), curving slightly posterior abaxially. Pleural furrow long (exs.) and deep, extending posterolaterally. Thoracic pleural spine continues curve of pleural furrow, slightly increasing in length from anterior to posterior. Pygidium large, sub-trapzoidal. Axis convex, divided into six segments by three firmly impressed anterior axial furrows, followed by two weakly impressed furrows. Terminal axial piece large, with posterior margin curved inward defining a pair of rounded lateral lobes. Postaxial region short in early part of this phase, becoming gradually longer ontogenetically, up to one seventh of pygidial length (sag.). Pleural lobe triangular, with even slope toward margin. Three pairs of pleural furrows 
extend posterolaterally. One pair of pygidial spines showing positive allometry through this phase, extending from anterior margin of pleural lobe, posterolaterally (exs.) and curved inward slightly. Postaxial emargination present.

Stage 4 (H4).- - Represented by seven specimens (Figs. 5.5, 5.6, 6.17; Table 1). Length varies between 32.51 and $85.0 \mathrm{~mm}$. Glabella extending strongly forward to anterior border furrow. Preglabellar field absent. Genal spine long, extending up to T6. Hypostome shield-shaped. Hypostomal anterior border short (sag.), narrow (tr.), curved ventrally. Anterior wing extending posterolaterally. Lateral border narrow (tr.). Anterior lobe of hypostomal median body elliptical, distinctly convex. Posterior lobe of hypostomal median body slightly convex. Posterior border narrow, rounded and convex. Thoracic pleural lobe spines increase gradually in length from anterior to posterior. Pygidium large. Axis distinctly convex, divided into seven segments. Terminal axial piece large, convex, with paired lobes distinct. Single large pygidial spine pair, extends posteriorly. Postaxial region long (sag.) about one sixth of pygidial length (sag.).

Summary of morphological variation of ontogeny.-The length of the exoskeleton increases from $0.55 \mathrm{~mm}$ in the smallest protaspis up to $85.0 \mathrm{~mm}$ in the largest holaspis. The main morphological changes include: (1) cranidium circular in protaspis, becoming gradually trapzoidal towards M5 and then subtrapzoidal in $\mathrm{H} 3$ and thereafter; (2) glabella rod-like, reaching anterior margin in protaspis, becoming gradually cylindrical and then conical in $\mathrm{H} 1$ onwards (frontal area is present in $\mathrm{H} 2$ but ultimately disappearing in H4); (3) fixigena slightly convex, 1.5 times wider than glabella in protaspis, gradually diminishing in width until one third of glabellar width in H3 onwards; (4) eye ridge convex, fused with frontal glabellar lobe and extending posteriorly in meraspis, but in M13 beginning to separate from the glabella, and bifurcating in $\mathrm{H} 1$ and tapering posterolaterally; (5) librigenae gradually increasing in width until twice width of fixigena in $\mathrm{H} 3$ onwards; (6) genal spine appears on librigenae in M4, with positive allometry throughout rest of meraspid and early holaspid phases, reaching up to the sixth thoracic segment in $\mathrm{H} 4$; (7) posterior border of librigena migrates posteriorly from an initially advanced position, anterior of the genal angle, to a position in which the adaxial base of the spine is opposite to the posterior corner of the cranidium, or even behind to it; (8) from M2 until M9 the position of the longest pleural spine moves posteriorly from $\mathrm{T} 1$ to $\mathrm{T} 5$, but from M10 all spines become relatively short and their size distinction diminishes (in the holaspid phase 3 , a gradual increase in the relative spine length of more posterior spines becomes evident); and (9) the sub-rectangular pygidium remains relatively small until the middle of the $\mathrm{H} 2$ stage, after which it becomes large and sub-trapezoidal, with the single pair of pygidial spines markedly increasing in length ontogenetically, ultimately reaching up to $13.03 \mathrm{~mm}$ long.

Growth rate.-Based on data from successive instars (Fig. 7) from the interval meraspid 2 to meraspid 13 (based on a successive series of instars each with a minimum sample size of at least one specimen) the length of the cranidium showed an average per-molt growth rate of 1.08 (AGR of Fusco et al.,

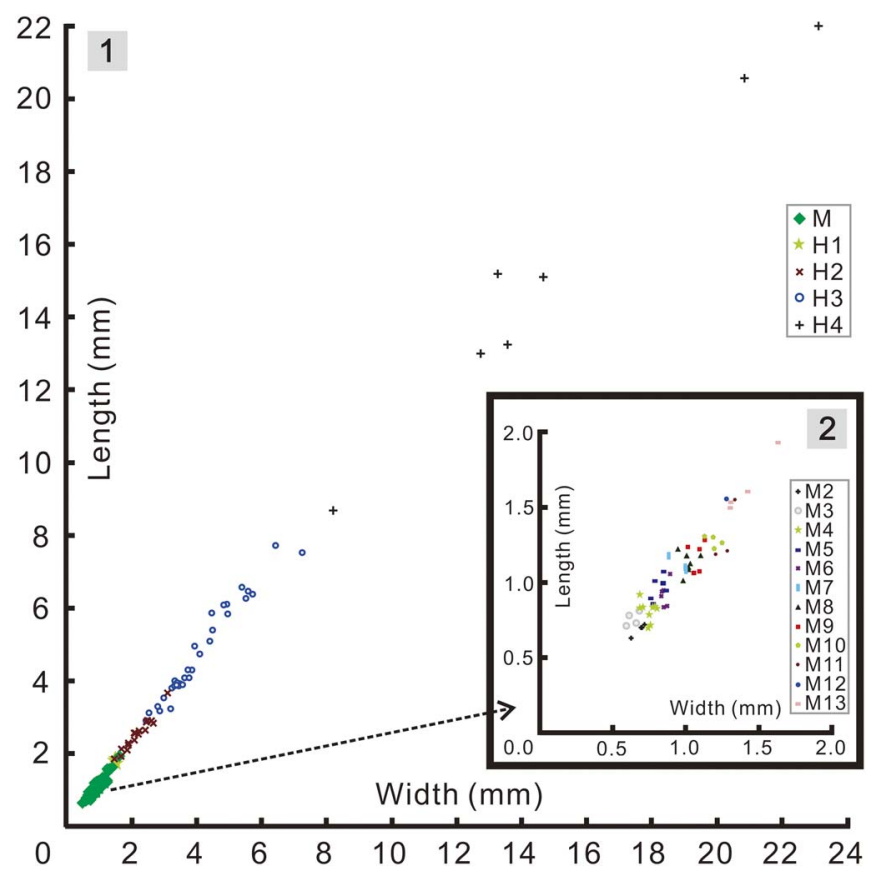

Figure 7. Bivariate scatter diagrams of cranidial growth in Zhangshania typica: (1), pooled data for the meraspid and holaspid phases; (2), enlargement of the meraspid portion in Figure 7.1.

2012), and an index of conformity to Dyar's rule of 0.85 (IDC of Fusco et al., 2012). The growth rate is at the low end of those reported for trilobites (Fusco et al., 2012, table 1), but similar to that seen among some other articulated specimens, such as A. koninckii, preserved in mudstones. The IDC value is similarly a little lower than that known for other meraspid cephala (Fusco et al., 2012, table 2).

\section{Discussion}

Antennae.-The antennae of Z. typica are like those of some other redlichiids in that they extend well beyond the cephalon and exceed it in length. In Z. typica paired spines are inserted into the anterior corners of the six most proximal articles exposed; one of the pair faces adaxially, the other faces abaxially. Conversely, on more distal articles only a single spine is evident, directed adaxially from their inner, distal side. This is different from the condition in Eoredlichia intermedia, in which eight or ten basal articles bear single spines that face adaxially (Hou et al., 2009). A wider review of antennal structures in and among trilobites will be presented elsewhere.

Trunk development.-The almost complete series permits study of the progressive development of trunk segmentation of Z. typica (Fig. 8). From this series, it is evident that one thoracic segment was released from the anterior margin of the meraspid pygidium as one new segment was added subterminally, indicating that the meraspid pygidium experienced an extended equilibrium phase (Simpson et al., 2005). As individuals entered the holaspid phase, the number of segments expressed in the pygidium continued to increase. The net result is that initially the holaspid pygidium had one more segment than the meraspid pygidium. After the $\mathrm{H} 1$ phase, the holaspid pygidium continued 


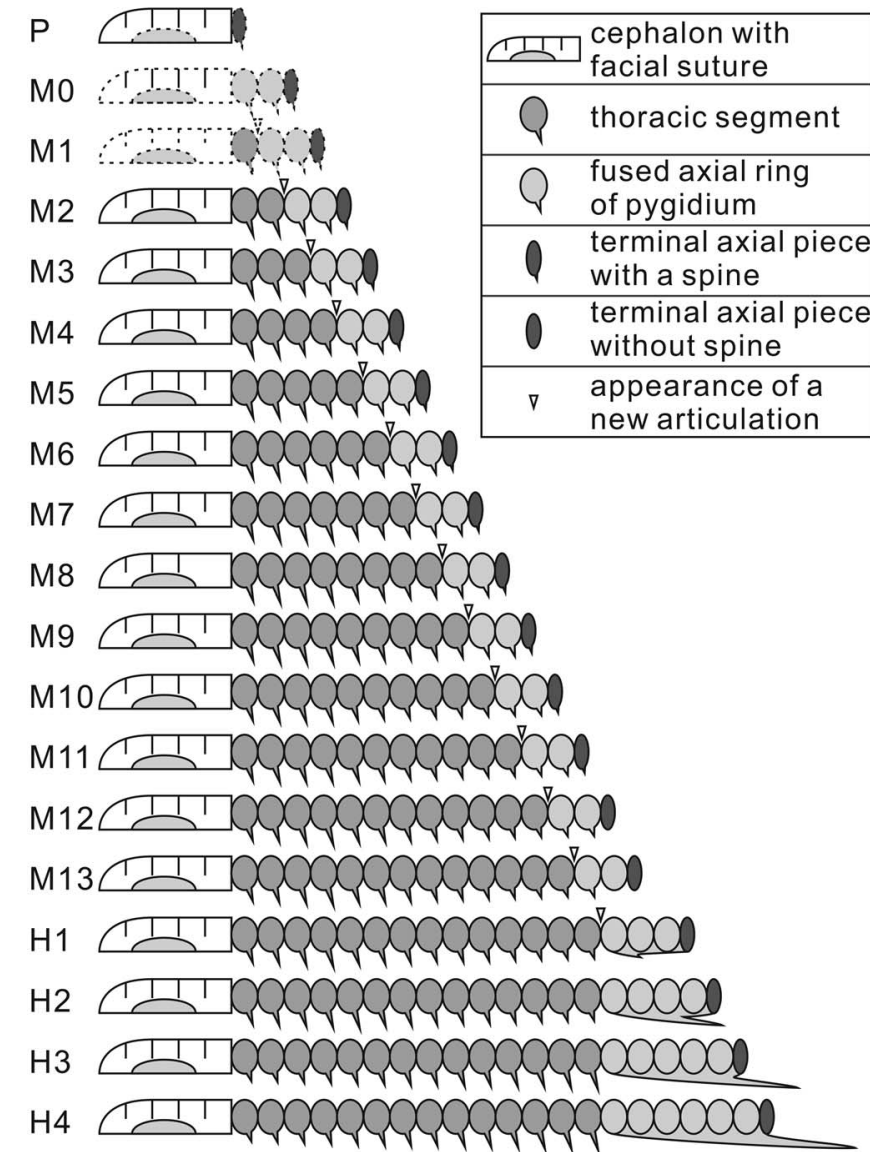

Figure 8. Reconstruction of the trunk segmentation schedule of Zhangshania typica. Dotted lines represent inferred stages not found but anticipated based on the known sample. Note progressive rearward shift of the longest trunk spines through ontogeny.

to express additional segments until a form was reached with seven axial rings, which defines onset of the last stage of holaspid growth, holaspid stage 4 . The trunk development was thus protarthrous, because onset of the holaspid phase significantly preceded onset of the epimorphic phase (Hughes et al., 2006).

Relative to Redlichia and Eoredlichia, in which the holaspid pygidium is a small structure throughout ontogeny, the holaspid pygidium of gigantopygids is notable both for its relatively large size and higher number of segments. This enlarged condition is even more marked in the Yinitidae, which also show fewer thoracic segments in the holaspid phase than in gigantopygids. The meraspid pygidium in Z. typica, in contrast, is a small structure throughout that growth phase. Accordingly, the transition from the meraspid to holaspid phases was accompanied by a marked change in pygidial growth mode in this species. During the extended equilibrium phase (Simpson et al., 2005) the meraspid pygidium showed limited size increase because expression of new segments near the rear of the structure was matched by release of segments from its anterior into the thorax. The molt transitioning into the holaspid phase, however, may have expressed more than a single segment (Fig. 8), and the pygidium thereafter apparently intermittently accumulated additional segments during the early phases until H4 was reached. This pattern of segment accretion, combined with the growth of the existing segments, and possibly also accelerated growth rates toward the posterior of the trunk (Fusco et al., 2014, 2016), may have ultimately permitted the holaspid pygidium to occupy a much larger proportion of the total exoskeletal area than it achieved in meraspis.

Addition of segments into the pygidium during the early part of the holaspid phase raises the question of whether the holaspid stages could be successive instars. To be so, the average per-molt growth rate between $\mathrm{H} 1-\mathrm{H} 2$ and between H2-H3 would have been 1.28 and 1.89, respectively (Fig. 7). Factors of the latter magnitude are not commensurate with those known from any trilobite (Fusco et al., 2012), and it seems unlikely that growth increment would have accelerated so markedly from the meraspid average of 1.08. Accordingly, the additional terminal trunk segments seem likely to have been expressed intermittently over a series of molts, and perhaps as many as 2 or 3 between $\mathrm{H} 1-\mathrm{H} 2$ if meraspid growth rates persisted into the holaspid phase. Such a change, from the regular expression of new trunk segments in each molt during much of the anamorphic phase to an apparently intermittent pattern of segment accretion toward the end of the anamorphic phase is unusual among hemianamorphic arthropods, as is the idea that molts accompanied by the expression of new segments (accumulation phase) alternate with those that do not (equilibrium phase). However, such alternation has been reported in other trilobites, for example during the meraspid growth of Shumardia (Conophyrs) salopiensis (see Hughes et al., 2006, fig. 4C) or possibly in Hunanocephalus ovalis (see Dai et al., 2014; but see also Hou et al., 2015). Another possibility is that there is some intraspecific phenotypic variation in the number of holaspid pygidial segments expressed in Z. typica. However, such phenotypic variation cannot explain the absence of small holaspid pygidia with 7 segments, the smallest of which occurs well above the size threshold of the meraspid-holaspid transition.

A notable feature of later holaspid Z. typica is the extremely long pygidial spines that cannot be directly associated with any particular pygidial segment. Because these spines only appear late in meraspid ontogeny, in order to reach such large size their growth rate must have been very high relative to those that preceded them in the trunk. One factor partly responsible for this could be an anteriorly declining growth gradient operating throughout the trunk, such that posterior segments grew at marked higher growth rates. Such gradients are known to have operated in trilobites (Fusco et al., 2014, 2016), and might explain the apparent rearward migration of the position of the longest pleural spine during meraspid ontogeny, as the growth rates of anterior segments were superseded by those behind them. It will be interesting to test for the presence of such a growth gradient in a biometric study of choice specimens.

The cessation of segment release in the holaspid pygidium resulted in a structure in which the development of segmental architecture related to articulation, necessary in the meraspid pygidium, was not essential to its function. A consequence of this is that features of the holaspid pygidium, such as spines, that almost certainly originated related to a particular segment, could lose their segment-specific identity and become part of a 
broader, integrated structure, presumably with an adaptive function related to the pygidium as a whole, rather than an entity composed of individual segments. The condition in Z. typica thus in some ways presages the development of the highly tagmatized holaspid pygidia seen in several derived trilobite clades (Hughes, 2003; Zhu et al., 2013).

The ontogenies of several other redlichiid trilobites have been described in some detail (Kobayashi and Kato, 1951; Dai et al., 2008, 2014; Dai and Zhang 2012, 2013) and are broadly comparable to that of $Z$. typica. The only other redlichiid for which we have comparable detail for the development of segmentation is Eoredlichia intermediata, which has been reconstructed to show a similar equilibrium phase during known meraspid ontogeny. Given the thoracic segment-rich trunks of redlichiid species, the pattern of an extended equilibrium phase may be general for the meraspid phase in this group. However, the onset of the holaspid phase of E. intermediata is described as characterized by depletion of one segment, followed by molts in which the number of holaspid pygidial segments increased (Dai and Zhang, 2013). This pattern implies the temporary cessation of new trunk segment expression at the onset of the holaspid stage for one instar, followed by rejuvenation of segment generation in later instars prior to final cessation of segment generation at the onset of epimorphosis. An alternative explanation might be phenotypic variation in the number of trunk segments expressed in the holaspid pygidium of this species (see also Hou et al., 2015). Because no size data for the nine holaspid specimens were presented by Dai and Zhang (2013), it is not possible for us to evaluate this possibility further. Whatever the case, evidence for intermittent anamorphic expression of new segments in trilobites is now quite strong.

\section{Conclusions}

The ontogenetic series shows marked but progressive changes and demonstrates that Parazhangshania sichuanensis is a junior synonym of Zhangshania typica. The protarthrous development of Z. typica (Fig. 8) comprised an extended pygidial equilibrium phase in the meraspid phase, but on entering the holaspid phase, the number of pygidial segments increased and accumulation took place, although apparently not with a new segment expressed at every molt. A comparable pattern of early holaspid growth also appears to characterize Eoredlichia intermediata (see Dai and Zhang, 2013). During the meraspid phase, the length of $Z$. typica's cranidium increased by an average per-molt growth rate of 1.08 between successive instars. However, rates calculated for the holaspid stages $\mathrm{H} 1-\mathrm{H} 2$ and $\mathrm{H} 2-\mathrm{H} 3$ are much higher, and likely too great to suggest that each stage represents a single instar. The notably long holaspid pygidial spines must have had very high relative growth rates compared to some preceding them in the trunk. Individual segment identity was reduced within the holaspid pygidium. Trilobites preserved with soft tissues are rarely known. The antennae of $Z$. typica bear paired spines on at least six proximal articles and, moving distally, the individual articles gradually become twice as long as broad. The discovery of Z. typica in the Hongjingshao Formation of Kunming provides a basis for regional stratigraphic correlation across southern China, allowing definition of the
Yiliangella-Zhangshania biozone in the Yunnan area and serving as a marker of the base of the Tsanglangpuan Stage of the traditional Chinese early Cambrian stadial system.

\section{Acknowledgments}

This study was supported by the National Natural Science Foundation of China (41472022, U1402232), Department of Science and Technology, Yunnan Province (2015HA045), US National Science Foundation EAR-1124303, Scholarship Award for Excellent Doctoral Student of Yunnan Province. We thank T. Hegna, an anonymous reviewer, and the editors for their careful work that much improved the manuscript.

\section{Accessibility of supplemental data}

Data available from the Dryad Digital Repository: http://dx.doi. org/10.5061/dryad.7g1m9

\section{References}

Brandt, D.S., 2002, Ecdysial efficiency and evolutionary efficacy among marine arthropods: implications for trilobite survivorship: Alcheringa, v. 26, p. $399-421$.

Chang, W.-T., 1966, On the classification of Redlichiacea, with description of new families and new genera: Acta Palaeontologica Sinica, v. 14, p. 135-184. [in Chinese with English summary].

Chang, W.-T., Repina, L.D., and Geyer, G., 1997, Suborder Redlichiina, in Kaesler, R.L., ed., Treatise on Invertebrate Paleontology, Part O, Arthropoda 1, Trilobita, Revised. Volume 1: Introduction, Order Agnostida, Order Redlichiida: Boulder, Colorado and Lawrence, Kansas, Geological Society of America and University of Kansas, p. 429-470.

Dai, T., and Zhang, X.-L., 2012, Ontogeny of the redlichiid trilobite Metaredlichia cylindrica from the lower Cambrian (Stage 3) of South China: Journal of Paleontology, v. 86, p. 646-651.

Dai, T., and Zhang, X.-L., 2013, Ontogeny of the redlichiid trilobite Eoredlichia intermediata from the Chengjiang Lagerstätte, lower Cambrian, southwest China: Lethaia, v. 46, p. 262-273.

Dai, T., Zhang, X.-L., and Peng, S.-C., 2008, Ontogeny of the trilobite Yunnanocephalus yunnanensis from the Chengjiang lagerstätte, lower Cambrian, southwest China: Alcheringa, v. 32, p. 465-468. DOI:10.1080/ 03115510802418057

Dai, T., Zhang, X.-L., and Peng, S.-C., 2014, Morphology and ontogeny of Hunanocephalus ovalis (trilobite) from the Cambrian of South China: Gondwana Research, v. 25, p. 991-998.

Fusco, G., Hughes, N. C., Webster, M., and Minelli, A., 2004, Exploring developmental modes in a fossil arthropod: growth and trunk segmentation of the trilobite Aulacopleura konincki: American Naturalist, v. 163, p. 167-183.

Fusco, G., Garland, T. Jr., Hunt, G., and Hughes, N.C., 2012, Developmental trait evolution in trilobites: Evolution, v. 66, p. 314-329.

Fusco, G., Hong, P.S., and Hughes, N.C., 2014, Positional specification in the segmental growth pattern of an early arthropod: Proceedings of the Royal Society of B: Biological Sciences, v. 281, no. 1781: 20133017. DOI: 10.1098/rspb.2013.3037.

Fusco, G., Hong, P.S., and Hughes, N.C., 2016, Axial growth gradients across the postprotaspid ontogeny of the Silurian trilobite Aulacopleura koninckii: Paleobiology, v. 42, p. 426-438. DOI: http://dx.doi.org/10.1017/pab.2016.5.

Harrington, H.J., Moore, R.C., and Stubblefield, C.J., 1959, Morphological terms applied to Trilobita, in Moore, R.C., ed., Treatise on Invertebrate Paleontology, Part O, Arthropoda 1: New York and Lawrence, Kansas, Geological Society of America and University of Kansas Press, p. 117-126.

Hou, J.-B, Hughes, N.C., Lan, T., Yang, J., and Zhang, X.-G., 2015, Early postembryonic to mature ontogeny of the cheiruroideid trilobite Duodingia duodingensis from the lower Cambrian (Series 2) of southern China: Papers in Palaeontology, v. 1, p. 497-513.

Hou, X.-G., Clarkson, E.N.K., Yang, J., Zhang, X.-G., Wu, G.-Q., and Yuan, Z.-B., 2009, Appendages of early Cambrian Eoredlichia (Trilobita) from the Chengjiang biota, Yunnan, China: Earth and Environmenta Science Transactions of the Royal Society of Edinburgh, v. 99, p. 213-223.

Hughes, N.C., 2003, Trilobite tagmosis and body patterning from morphological and developmental perspectives: Integrative and Comparative Biology, v. 43, p. 185-206. 
Hughes, N.C., Chapman, R.E., and Adrain, J.M., 1999, The stability of thoracic segmentation in trilobites: a case study in developmental and ecological constraints: Evolution and Development, v. 1, p. 24-35.

Hughes, N.C., Minelli, A., and Fusco, G., 2006, The ontogeny of trilobite segmentation: a comparative approach: Paleobiology, v. 32, p. 602-627.

Hughes, N.C., Kř̌iž, J., Macquaker, J.H.S., and Huff, W.D., 2014, The depositional environment and taphonomy of the Homerian "Aulacopleura shales" fossil assemblage near Loděnice, Czech Republic (Prague Basin, Perunican microcontinent): Bulletin of Geosciences, v. 89, p. 219-238.

Hupé, P., 1953 (1952), Contribution a l'étude du Cambrien inférieur et du Précambrien III de l'Anti-Atlas Marocain: Division des mines et de la géologie, Service Géologique, Notes et Memoires, v. 103, 402 p.

Jell, P.A., and Adrain, J.M., 2003, Available generic names for trilobites: Memoirs of the Queensland Museum, v. 48, p. 331-535.

Kobayashi, T., and Kato, F., 1951, On the ontogeny and the ventral morphology of Redlichia chinensis with description of Alutella nakamuria, new gen. and sp: Journal of Faculty of Science of the University of Tokyo, Section 2, p. 100-143.

Li., S.-J., Kang, C.-L., and Zhang, X.-G., 1990, Sedimentary environment and trilobites of lower Cambrian Yuxiansi Formation in Leshan district, Sichuan: Bulletin of the Chengdu Institute of Geology and Minera Resources, the Chinese Academy of Geological Sciences, No. 12, p. 37-60. [in Chinese with English summary].

Lu, Y.-H., 1945, Early Middle Cambrian Faunas from Meitan: Bulletin of the Geological Society of China, v. 25, p. 185-199.

Lu, Y.-H., 1961, New lower Cambrian trilobites from eastern Yunnan: Acta Palaeontologica Sinica, v. 9, p. 299-325. [in Chinese with English summary].

Luo, H.-L., Jiang, Z.-W., and Tang, L.-D., 1994, Stratotype section for Lower Cambrian stages in China: Yunnan Science and Technology Press, Kunming, 183 p. [in Chinese with English summary]

Luo, H.-L., Li, Y., Hu, S.-X., Fu, X.-P., Hou, S.-G., Liu, X.-Y., Chen, L.-Z., Li, F.-J., Pang, J.-Y., and Liu, Q., 2008, Early Cambrian Malong fauna and Guanshan fauna from Eastern Yunnan, China: Kunming, China, Yunnan Science and Technology Press, 134 p. [in Chinese].

McNamara, K. J., 1986, The role of heterochrony in the evolution of Cambrian trilobites: Biological Reviews, v. 61, p. 121-156.

Minelli, A., Fusco, G., and Hughes, N.C., 2003, Tagmata and segment specification in trilobites: Special Papers in Palaeontology, v. 70, p. 31-43.

Peng, S.-C., 2009, The newly developed Cambrian biostratigraphic succession and chronostratigraphic scheme for South China: Chinese Science Bulletin v. 54, p. 2691-2698.

Peng, S.-C., Babcock, L.E., and Cooper, R.A., 2012, The Cambrian period, in Gradstein, F.M., Ogg, J.G., Schmitz, M., and Ogg, G., eds., The Geologic Time Scale: Boston, Elsevier, p. 437-488.

Poulsen, C., 1927, The Cambrian, Ozarkian and Canadian faunas of northwest Greenland: Meddelelser om GrØnland, v. 70, p. 233-343.

Rasetti, F., 1972, Cambrian trilobite faunas of Sardinia: Accadememia Nazionale dei Lincei, Memorie, v. 11, p. 1-100.

Richter, R., 1932, Crustacea (Paläontologie), in Dittler, R., Joos, G., Korschelt, E., Linek, G., Oltmanns, F., and Schaum, K., eds., Handwörterbuch der Naturwissenschaften, 2nd ed: Jena, Gustav Fisher, p. 840-863.

Simpson, A.G., Hughes, N.C., Kopaska-Merkel, D.C., and Ludvigsen, R., 2005 , Development of the caudal exoskeleton of the pliomerid trilobite Hintzeia plicamarginis new species: Evolution \& Development, v. 7, p. 528-541.
Speyer, S.E., and Brett, C.E., 1986, Trilobite taphonomy and middle Devonian taphofacies: Palaios, v. 1, p. 312-327.

Whittington, H.B., and Kelly, S.R.A., 1997, Morphological terms applied to Trilobita, in Kaesler, R.L., ed., Treatise on Invertebrate Paleontology, Part O, Arthropoda 1, Trilobita, Revised. Volume 1: Introduction, Order Agnostida, Order Redlichiida: Boulder, Colorado and Lawrence, Kansas, Geological Society of America and University of Kansas, p. 313-329.

Xiang, L.-W., Zhu, Z.-L., Li, S.-J., and Zhou, Z.-Q., 1999, Stratigraphy of China-Cambrian System: Beijing, Geology Publishing House, 95 p. [In Chinese].

Yang, J., Ortega-Hernández, J., Butterfield, N.J., and Zhang, X.-G., 2013 , Specialized appendages in fuxianhuiids and the head organization of early euarthropods: Nature, v. 494, p. 468-471.

Yang, J., Smith, M.R., Lan, T., Hou, J.-B., and Zhang, X.-G., 2014, Articulated Wiwaxia from the Cambrian stage 3 Xiaoshiba Lagerstätte: Scientific Reports, v. 4, n. 4643 doi: doi: 10.1038/srep04643.

Yang, J., Ortega-Hernández, J., Gerber, S., Butterfield, N.J., Hou, J.-B., Lan, T. and Zhang, X.-G., 2015, A superarmored lobopodian from the Cambrian of China and early disparity in the evolution of Onychophora: Proceedings of the National Academy of Sciences of the United States of America, v. 112, p. $8678-8683$

Yang, J., Ortega-Hernández, J., Butterfield, N.J., Liu, Y., Boyan, G.S., Hou, J.-B., Lan, T., and Zhang, X.-G., 2016a, Fuxianhuiid ventral nerve cord and early nervous system evolution in Panarthropoda: Proceedings of the National Academy of Sciences of the United States of America, v. 113, p. $2988-2993$.

Yang, J., Ortega-Hernandez, J., Lan, T., Hou, J.-B., and Zhang, X.-G., 2016b, A predatory bivalved euarthropod from the Cambrian (Stage 3) Xiaoshiba Lagerstätte, South China: Scientific Reports, v., 6, 27709. DOI: 10.1038/ srep27709.

Yin, G.-Z., and Li, S.-J., 1978, Trilobita, in Guizhou Working Group of Stratigraphy and Paleontology, ed., Atlas of the Palaeontology of Southwest China, Guizhou Province: Beijing, Geological Publishing House, p. 385-830. [In Chinese].

Zhang, W.-T., Lu, Y.-H., Zhu, Z.-L., Qian, Y.-Y., Lin, H.-L., Zhou, Z.-Y., Zhang, S.-G., and Yuan, J.-L., 1980, Cambrian trilobite faunas of southwestern China: Palaeontologica Sinica, New Series B, 16, 497 p. [In Chinese with English summary].

Zhang, X.-G., and Clarkson, E. N. K., 2012, Phosphatized eodiscoid trilobites from the Cambrian of China: Palaeontographica, Abteilung A v. 297 , p. $1-121$.

Zhou, Z.-Y., and Yuan, J.-L., 1980, Lower Cambrian trilobite succession in southwest China: Acta Palaeontologica Sinica, v. 19, p. 331-339. [In Chinese with English summary].

Zhu, X.-J., Hughes, N. C., and Peng, S.-C., 2013, Onset of maturity and ontogenetic tagmatization of the pygidium in the development of Lonchopygella megaspina (Trilobita, later Furongian, Cambrian): Journal of Paleontology, v. 87, p. 472-483.

Accepted 7 June 2016 